\title{
Messenger RNA Expression and Synthesis of Endothelin-1 along Rat Nephron Segments
}

Kazutomo Ujiie, Yoshio Terada, Hiroshi Nonoguchi, Masanori Shinohara, Kimio Tomita, and Fumiaki Marumo Second Department of Internal Medicine, Tokyo Medical and Dental University, Tokyo 113, Japan

\begin{abstract}
The kidney both produces and responds to endothelin. We examined the production and the expression of mRNA of endothelin-1 (ET-1) in tubule suspensions and microdissected nephron segments. ET-1 production was measured by RIA using an ET-1-specific antibody. We applied the reverse transcription and polymerase chain reaction (PCR) technique to detect ET-1 mRNA along the nephron segments. Stimulation of ET-1 production was observed in the presence of FCS and transforming growth factor- $\beta$ ( TGF- $\beta$ ) in inner medullary tubules but not in cortical or outer medullary tubule suspensions. Among dissected nephron segments, ET-1 production was observed in glomeruli and inner medullary collecting ducts (IMCD), whereas it was negligible in proximal convoluted tubules (PCT) and medullary thick ascending limbs (MAL). In addition, the PCR product of ET-1 mRNA was also higher in glomeruli and IMCD, whereas it was undetectable in PCT and MAL. Furthermore, FCS and TGF- $\beta$ increased ET-1 mRNA in microdissected glomeruli and IMCD. These data clearly demonstrated that the production sites of ET-1 are glomeruli and IMCD among the nephron segments. ET-1 is an autocrine factor in these sites. (J. Clin. Invest. 1992. 90:1043-1048.) Key words: endothelin-1 1 reverse transcription • polymerase chain reaction • messenger RNA • glomeruli • inner medullary collecting ducts
\end{abstract}

\section{Introduction}

Endothelin (ET) ${ }^{1}$ is a 21 -amino acid vasoconstrictor peptide produced by vascular endothelial cells $(1-3)$. ET has three isotypes: ET-1, ET-2, and ET-3 (4). ET-1 receptors are widely distributed in the body, including the brain, spinal cord, spleen, skeletal muscle, and kidneys (5-8). Intravenous administration of ET-1 increased total peripheral resistance, arterial pressure, and left atrial pressure, and decreased heart rate and car-

Address correspondence to Dr. Kimio Tomita, Second Department of Internal Medicine, Tokyo Medical and Dental University, 1-5-45 Yushima, Bunkyo-ku, Tokyo 113, Japan.

Received for publication 10 October 1991 and in revised form 18 February 1992

1. Abbreviations used in this paper: ANP, atrial natriuretic peptide; CCD, cortical collecting ducts; ET, endothelin; GAPDH, glyceraldehyde-3-phosphate dehydrogenase; iIMCD, initial inner medullary collecting ducts; IMCD, inner medullary collecting ducts; MAL, medullary thick ascending limbs; OMCD, outer medullary collecting ducts; PCT, proximal convoluted tubules; PCR, polymerase chain reaction; RT, reverse transcription; RT-PCR, polymerase chain reaction technique coupled with reverse transcription; TGF- $\beta$, transforming growth factor- $\beta$; tIMCD, terminal IMCD; TNF- $\alpha$, tumor necrosis factor- $\alpha$.

J. Clin. Invest.

(c) The American Society for Clinical Investigation, Inc.

$0021-9738 / 92 / 09 / 1043 / 06 \$ 2.00$

Volume 90, September 1992, 1043-1048 diac output $(9,10)$. In the kidney, ET-1 decreased renal blood flow by increasing both afferent and efferent arteriolar resistance, and it decreased GFR by decreasing the glomerular capillary ultracoefficient (9-14). It has recently been revealed that ET-1 also causes diuresis and natriuresis despite a decrease in $\operatorname{GFR}(9,12)$, suggesting a direct tubular site of action. Autoradiographic studies showed binding sites to ET-1 not only in glomeruli and the vascular system but also in the inner medulla, possibly in inner medullary collecting ducts (IMCD) $(15,16)$. This binding pattern is quite similar to that of atrial natriuretic peptide (ANP) (17). A recent immunohistochemical study showed the presence of ET-1 binding sites in proximal tubules and IMCD as well as glomeruli and the vascular system (18). These histological studies have indicated the presence of ET-1 target sites in nephron segments as well as the vascular system.

Recently, data concerning tubular actions of ET-1 have accumulated. Garvin and Sanders (19) showed that ET-1 inhibited water transport in rat proximal straight tubules. ET-1 inhibited arginine vasopressin (AVP)-stimulated cAMP accumulation in cortical collecting ducts (CCD), outer medullary collecting ducts (OMCD), and IMCD (20). ET-1 inhibited Na-K-ATPase activity in IMCD (21). ET induced an increase of intracellular $\mathrm{Ca}^{++}$concentration in glomeruli and collecting ducts $(14,22,23)$. ET-1 inhibited active chloride absorption and water absorption in CCD and IMCD of rats $(24,25)$. These studies, taken together with histological studies, indicate that the target sites of ET-1 along the nephron are the glomeruli, proximal tubules, and the collecting ducts.

However, little is known concerning the production sites of ET-1 in the kidney. ET was originally found in culture medium of vascular endothelial cells (1-3), suggesting that the vascular system could be the major source of renal ET-1 synthesis. Mesangial cells are known to produce ET-1 $(26,27)$. ET-1 is also produced by cultured epithelial cells, such as LLC-PK $_{1}$ and MDCK cells, in which ET-1 increased intracellular $\mathrm{Ca}^{++}(28)$. The sites of ET-1 production along the nephron are not clear. Recently, ET-1 production was shown in primary cultured renal tubules from proximal convoluted tubules (PCT), medullary thick ascending limbs (MAL), CCD, and $\operatorname{IMCD}(29,30)$. An in situ hybridization study showed the presence of ET-1 mRNA in glomeruli, vasa recta, and inner medulla (31). However, it is not known if intact renal tubules can produce ET-1. Because the plasma concentration of ET-1 is low, it has been suggested that ET-1 is a local hormone rather than a circulating one (32). Therefore, it would be quite important to know the local production sites of ET-1 in order to understand the autocrine or paracrine action of ET-1 in the kidney.

The purpose of our study was to investigate whether the nephron segments produce ET-1. We used two different methods to determine the sites of ET-1 production along the nephron. We examined ET-1 production in microdissected nephron segments using RIA, and ET-1 mRNA distribution using a polymerase chain reaction technique coupled with reverse transcription (RT-PCR). 


\section{Methods}

Preparation of tubule suspensions and microdissected nephron segments. Tubule suspensions were used to determine the time course and best condition to stimulate ET-1 production. Male Sprague-Dawley rats, weighing $150-250 \mathrm{~g}$, and male New Zealand White rabbits, weighing $1.5-2.0 \mathrm{~kg}$, were used to make tubule suspensions as previously described (33). In brief, after perfusion with solution 1, the left kidney was divided into three parts: cortex, outer medulla, and inner medulla. Solution 1 contained the following $(\mathrm{mM}): 130 \mathrm{NaCl}, 5 \mathrm{KCl}, 1$ $\mathrm{NaH}_{2} \mathrm{PO}_{4}, 1 \mathrm{MgSO}_{4}, 1 \mathrm{Ca}$ lactate, $2 \mathrm{Na}$ acetate, 5.5 glucose, $5 \mathrm{~L}$-alanine, 2 L-leucine, and 10 Hepes; $\mathrm{pH}$ was adjusted to 7.4 by $\mathrm{NaOH}$. After mincing, each part was incubated in solution 1 with $0.1 \%$ BSA and $0.1 \%$ collagenase (Sigma Chemical Co., St. Louis, MO) in the presence of $100 \% \mathrm{O}_{2}$ for $30 \mathrm{~min}$ (for cortical tubule suspensions), or 45 min (for outer medullary tubule suspensions), or $60 \mathrm{~min}$ (for inner medullary tubule suspensions). Solution 1 was replaced with solution 2 just before the incubation of tubule suspensions or microdissected nephron segments. Solution 2 contained the following (mM): 118 $\mathrm{NaCl}, 25 \mathrm{NaHCO}_{3}, 2.5 \mathrm{~K}_{2} \mathrm{HPO}_{4}, 1 \mathrm{MgSO}_{4}, 1 \mathrm{Ca}$ lactate, $2 \mathrm{Na}$ acetate, 5.5 glucose, $5 \mathrm{~L}$-alanine, and $2 \mathrm{~L}$-leucine, and was bubbled with $5 \%$ $\mathrm{CO}_{2} / 95 \% \mathrm{O}_{2}$. Microscopic study showed that tubule suspensions from cortex, outer medulla, and inner medulla were rich in PCT, MAL, and IMCD, respectively. To confirm the viability, we measured ANP-stimulated cGMP accumulation and AVP-stimulated cAMP accumulation in tubule suspensions from inner medulla, as described previously $(33,34)^{2}$

Nephron segments were microdissected from Sprague-Dawley rats, weighing $80-150 \mathrm{~g}$ as previously described $(33,34)$. Microdissected nephron segments were glomeruli, PCT, MAL, and IMCD. 50-500 glomeruli and 150-350-mm-length tubules were used as one sample to determine ET-1 production. Since we had to use very long tubules for the ET-1 production study, we combined initial IMCD (iIMCD) and terminal IMCD (tIMCD) as IMCD. When the tubule length was not long enough, supernatants were pooled after the incubation until the total length of tubules became $>150 \mathrm{~mm}$.

Measurements of ET-1 production in tubule suspensions and microdissected nephron segments. Tubule suspensions or microdissected nephron segments in $100 \mu \mathrm{l}$ of solution 2 were transferred to the bottom of a freshly siliconized glass vial. FCS (Gibco, Gaithersburg, MD), transforming growth factor $-\beta$ (TGF- $\beta)(16 \mathrm{ng} / \mathrm{ml})($ Collaborative Research, Inc., Bedford, MA), or tumor necrosis factor- $\alpha$ (TNF $\alpha)(90$ $\mathrm{ng} / \mathrm{ml}$ ) (Hayashi Biochemical Laboratory, Tokyo, Japan) was added to the solution. The final volume of each sample was 600 or $1,200 \mu \mathrm{l}$.

Incubation times were varied from 4.5 to $24 \mathrm{~h}$ in tubule suspension experiments. Microdissected nephron segments were incubated for 16 h. After incubation at $37^{\circ} \mathrm{C}$ with $5 \% \mathrm{CO}_{2} / 95 \% \mathrm{O}_{2}$, an entire sample was transferred to a $1.5-\mathrm{ml}$ centrifuge tube and centrifuged for $10 \mathrm{~min}$ at 3,000 rpm. The supernatant was frozen until ET-1 was assayed. The RIA of ET-1 was performed using ET-1-specific antibody after the extraction of samples (32).

Determination of ET-1 mRNA expression along the nephron. Determination of ET-1 mRNA along the nephron was performed as previously described $(35,36)$. Microdissection of tubules was carried out in solution 1 containing $10 \mathrm{mM}$ vanadyl ribonucleoside complex (VRC) (Life Technologies, Gaithersburg, MD), a potent RNase inhibitor. We dissected the following structures: glomeruli, PCT, MAL, CCD,

2. ANP dose-dependently stimulated cGMP accumulation in tubule suspensions from inner medulla $(3.9 \pm 1.8,17.8 \pm 4.6$, and $61.2 \pm 6.4$ $\mathrm{fmol} / \mu \mathrm{g}$ protein $/ 3 \mathrm{~min}$ in the absence of ANP, and in the presence of $10^{-8}$ and $10^{-6} \mathrm{M}$ ANP, respectively, $\left.n=4\right)$. Dose-dependent AVP-stimulated cAMP accumulation was also observed in tubule suspensions from inner medulla ( $105 \pm 20,383 \pm 16$, and $588 \pm 42 \mathrm{fmol} / \mu \mathrm{g}$ protein $/ 3$ min in the absence of AVP and in the presence of $10^{-9}$ and $10^{-7} \mathrm{M}$ AVP, respectively, $n=4)$. These data are compatible with previous data (33) and showed the presence of receptors to ANP and AVP in tubule suspensions from inner medulla.
OMCD, iIMCD (outer 25\%) and tIMCD (inner 75\%), as well as the vasa recta bundle.

Microdissected structures were transferred to another dish filled with solution 1. Microdissected tubules, glomeruli, and vasa recta bundles were washed free of contaminating debris and vanadyl ribonucleoside complex, and then they were transferred to the RT-PCR reaction tubes. The tubules were rinsed three times with $10 \mu \mathrm{l}$ of ice-cold solution 1 containing $1 \mathrm{U} / \mu$ l of human placental RNase inhibitor and 5 mM DTT (Cleland's Reagent).

Reverse transcription (RT) was performed using a cDNA synthesis kit. After centrifuge of the reaction tubes, the RNase inhibitor solution was removed and $9 \mu \mathrm{l}$ of $2 \%$ Triton X-100, containing $1 \mathrm{U} / \mu \mathrm{l}$ of RNase inhibitor and $2 \mathrm{mM}$ DTT, was added to permeabilize the cells. Then $\mathrm{RT}$ components were added. The composition of $\mathrm{RT}$ components was as follows: $4 \mu$ l of buffer I, $1 \mu \mathrm{l}$ of RNase inhibitor, $2 \mu \mathrm{l}$ of deoxynucleotide mixture, $2 \mu \mathrm{l}$ of oligo dT ( 15 -mer) primer, and $2 \mu \mathrm{l}$ of avian myeloblastoma virus reverse transcriptase. The reaction tubes were incubated at $42^{\circ} \mathrm{C}$ for $60 \mathrm{~min}$ in the DNA thermal cycler (Astex, Tokyo, Japan). After this incubation, the tubes were incubated at $90^{\circ} \mathrm{C}$ for $5 \mathrm{~min}$ to stop the reaction and denature the RNA-cDNA complex. Then each tube was kept at $4^{\circ} \mathrm{C}$ until the addition of polymerase chain reaction (PCR) reagents.

PCR was performed using a DNA amplification reagent kit (GeneAmp; Perklin-Elmer Cetus, Norwalk, CT), with rat preproendothelin-1-specific primers prepared by a DNA synthesizer (Applied Biosystems, Tokyo, Japan). We designed a specific primer that is 20-25 nucleotides in length with $50-60 \%$ GC composition. The resultant high calculated $\operatorname{Tm}\left(>75^{\circ} \mathrm{C}\right)$ allows for a stringent annealing temperature during PCR cycles. The sequence of primer 1 (antisense) was 5'-AAGATCCCAGCCAGCATGGAGAGCG-3', which was defined by 675-699 bps (37). The ET primer 2 (sense) encompassed 157-177 bps and the sequence was 5'-CGTTGCTCCTGCTCCTCCTTGATGG-3' (37). ET primers 1 and 2 were designed to localize in separate exons (38). The cDNA amplification product was predicted to be $543 \mathrm{bps}$ in length. The third oligonucleotide was synthesized to serve as an amplification product-specific probe. This oligonucleotide (sense) includes 302-321 bps of cDNA and was positioned between ET primers 1 and 2 . The sequence of this oligonucleotide probe was 5'-CAAAGACCACAGACCAAGGG-3'.

To carry out PCR, $80 \mu \mathrm{l}$ of a PCR master mix was added to each tube, which contained $20 \mu \mathrm{l}$ of RT reaction buffer. $50 \mathrm{pmol}$ of primers 1 and 2 was used for each reaction. The final concentration of deoxynucleotides was $0.2 \mathrm{mM}$. The composition of reaction buffer was as follows (mM): 10 Tris- $\mathrm{HCl}$ ( $\mathrm{pH} 8.3$ ), $50 \mathrm{KCl}, 1.5 \mathrm{MgCl}_{2}$, and $0.001 \%$ (wt/vol) gelatin. Two and a half units of Taq DNA polymerase was used for each reaction. $100 \mu \mathrm{l}$ of mineral oil was overlayed, to prevent evaporation during the high temperature incubations. The tubes were placed in the DNA thermal cycler programmed as follows: $(a)$ first incubation at $94^{\circ} \mathrm{C}$ for $3 \mathrm{~min}$ (initial melt); $(b)$ and then, 40 cycles of the following sequential steps: $1 \mathrm{~min}$ at $94^{\circ} \mathrm{C}$ (melt), $1 \mathrm{~min}$ at $60^{\circ} \mathrm{C}$ (anneal), and $3 \mathrm{~min}$ at $72^{\circ} \mathrm{C}$ (extend); (c) final incubation at $72^{\circ} \mathrm{C}$ for 7 min (final extension). Then the samples were kept at $4^{\circ} \mathrm{C}$ until PCR products were assayed.

$90 \mu$ l of samples was transferred to new tubes and precipitated by ethanol. The DNA pellets were resuspended and the PCR products were size fractionated by agarose gel electrophoresis. After staining by ethidium bromide, DNA bands were visualized with an ultraviolet transilluminator (Spectoline; Funakoshi, Tokyo, Japan).

For Southern blot analysis, gels were blotted onto a Gene Screen (Dupont New England Nuclear, Boston, MA) and were baked at $80^{\circ} \mathrm{C}$ for $4 \mathrm{~h}$ to fix the DNA. The synthetic oligonucleotide probes described above were end-labeled with ${ }^{32} \mathrm{P}$ as described previously $(35,36)$. Prehybridization/hybridization washes were also done as previously described $(35,36)$.

Detection of ET-1 $\mathrm{mRNA}$ expression in glomeruli and IMCD incubated with FCS and TGF- $\beta$. To see the effect of FCS and TGF- $\beta$ on ET-1 mRNA expression, five glomeruli or $10 \mathrm{~mm}$ of microdissected IMCDs were incubated with or without FCS and TGF- $\beta$ for $6 \mathrm{~h}$. We also performed RT-PCR of glyceraldehyde-3-phosphate dehydroge- 
nase (GAPDH) as an internal standard. The primers were defined by the following cDNA base sequence (39): primer 1 (antisense), bases 795-814, sequence, 5'-AGATCCACAACGGATACATT-3'; primer 2 (sense), bases 506-525, sequence 5'-TCCCTCAAGATTGTCAGCAA-3'. The predominant $\mathrm{CDNA}$ amplification product was predicted to be 309 bp in length. After RT, a 20- $\mu$ l sample was divided into $15 \mu \mathrm{l}$ for ET-1 and $5 \mu$ l for GAPDH. The volume was adjusted to $20 \mu \mathrm{l}$ with sterile water. Then parallel PCR reactions were performed as described above. 30 cycles of PCR was performed since a previous study showed a linear relationship between PCR cycles and PCR products (mRNA) for up to 30 cycles of PCR (36).

Protein assay. The protein contents of tubule suspensions were determined using a protein assay kit (Bio-Rad Laboratories, Richmond, CA). Albumin was used as a standard.

Statistics. Statistical analysis was performed using analysis of variance (followed by Dunnet's multiple comparison ) or Student's $t$ test. A $P<0.05$ was considered significant. Results were expressed as mean \pm SE.

\section{Results}

ET-1 production by tubule suspensions in the rabbit and rat. In the presence of $10 \%$ FCS, tubule suspensions from rabbit inner medulla showed a higher ability to produce ET-1 than those from cortex and outer medulla $(0.03 \pm 0.03,0.16 \pm 0.14$, and $20.9 \pm 5.8 \mathrm{pg} / \mathrm{mg}$ protein $/ 4.5 \mathrm{~h}$ in cortical, outer medullary, and inner medullary tubule suspensions, respectively, $n=4$ ) (Fig. $1 a$ ). TGF- $\beta$ or TNF- $\alpha$ had no additive effects with FCS on ET-1 production.

We next used tubule suspensions from the rat inner medulla, since later experiments use microdissected tubules from rats. A time course experiment showed that ET-1 production in inner medullary tubule suspensions increased linearly up to $24 \mathrm{~h}$ in the presence of $10 \%$ FCS (Fig. $1 \mathrm{~b}$ ). FCS, up to $15 \%$, dose-dependently stimulated ET-1 production (Fig. $1 \mathrm{c}$ ). In contrast to rabbit, TGF- $\beta$ stimulated ET-1 production in rat inner medullary tubule suspensions $(8.0 \pm 1.5,12.7 \pm 1.7$, and $7.5 \pm 2.3 \mathrm{pg} / \mathrm{mg}$ protein $/ 16 \mathrm{~h}$ in $10 \%$ FCS only, FCS + TGF- $\beta$, and FCS + TNF- $\alpha$, respectively, $n=5, P<0.05)$.

ET-1 production along the rat nephron segments. From the results of tubule suspensions, ET-1 production in microdissected nephron segments was measured in the presence of $15 \%$ FCS and TGF- $\beta$. ET- 1 production was high in glomeruli and IMCD $(20.4 \pm 5.0 \mathrm{fg} / \mathrm{glm} / 16 \mathrm{~h}$ and $28.1 \pm 12.2 \mathrm{fg} / \mathrm{mm} / 16 \mathrm{~h}$, respectively, $n=4-5$ ) (Fig. 2 ). ET-1 production in PCT and MAL was almost negligible $(0.22 \pm 0.17$ and $0.89 \pm 0.77 \mathrm{fg} /$ $\mathrm{mm} / 16 \mathrm{~h}$, respectively, $n=4-5$ ).

ET-1 mRNA distribution along the rat nephron segments. Fig. 3 shows typical results from agarose gel electrophoresis and Southern blot analysis of amplification products by RT-PCR of ET-1 mRNA in microdissected structures. A single band was consistently found from glomeruli, iIMCD, and tIMCD. This band was of the predicted size ( $543 \mathrm{bp}$ ). The Southern blots of the gels demonstrated specific binding of the oligonucleotide probe to the 543-bp product, confirming its identity. The sequences of ET-1 and -2 primers localized to different exons with the genomic sequence $(37,38)$. Thus, amplification of genomic DNA cannot be the predicted size of $543 \mathrm{bp}$. In the absence of RT, the 543-bp band was not seen and there was no other recognizable band (not shown).

The largest signal was found in the glomeruli among the nephron segments. Pronounced bands were also detected from
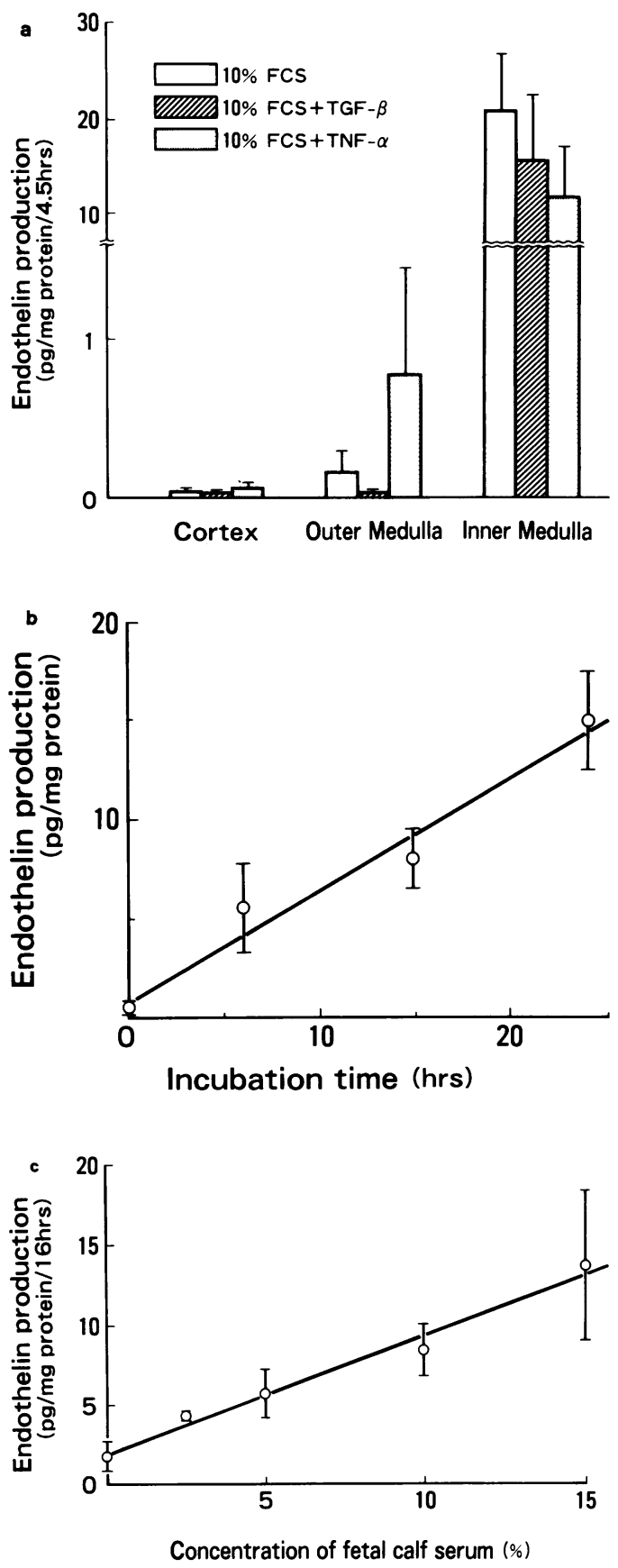

Figure 1. (a) ET-1 production in tubule suspensions from cortex, outer medulla, and inner medulla of rabbits. Tubule suspensions from three parts of the rabbit kidney were incubated for $4.5 \mathrm{~h}$ in the presence of $10 \%$ FCS, $10 \%$ FCS plus TGF- $\beta(16 \mathrm{ng} / \mathrm{ml})$, or $10 \%$ FCS plus TNF- $\alpha(90 \mathrm{ng} / \mathrm{ml})$. ET-1 in the supernatants was measured using radioimmunoassay. ( $b$ ) Time-dependent ET-1 production in tubule suspensions from inner medulla of rats. $10 \%$ FCS was present. $(c)$ Effect of FCS on ET-1 production by inner medullary tubule suspensions of rats. Tubule suspensions were incubated for $16 \mathrm{~h}$ at $37^{\circ} \mathrm{C}$.

iIMCD and IIMCD in the predicted size. However, no bands were found from other nephron segments.

ET-1 $\mathrm{mRNA}$ induction by FCS and TGF- $\beta$ in rat glomeruli and IMCD. Fig. 4, $a$ and $b$, (top panels) shows a typical agarose gel electrophoresis with the band of predicted size ( $543 \mathrm{bp}$ ). The middle portion of Fig. 4 shows a Southern blot of the gel. 


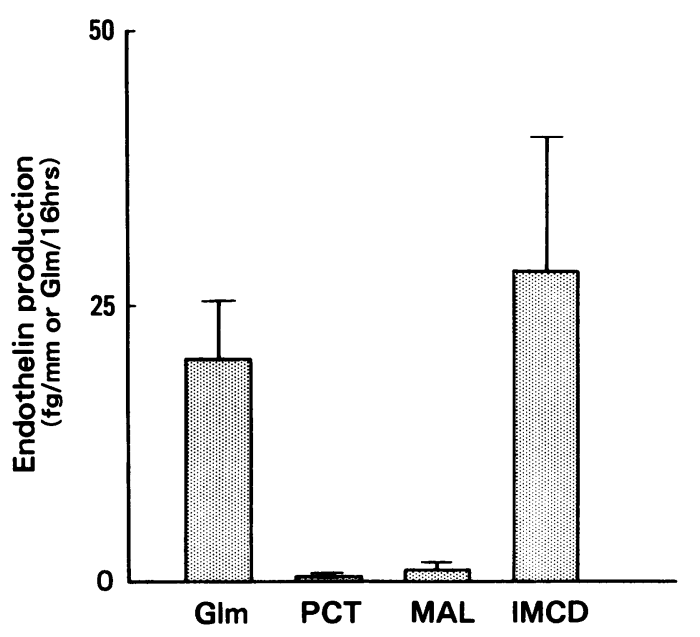

Figure 2. ET-1 production by microdissected glomeruli and nephron segments. 50-500 glomeruli and 150-350-mm-long nephron segments ( $P C T, M A L$, and $I M C D)$ were incubated with $15 \% \mathrm{FCS}$ and TGF- $\beta(16 \mathrm{ng} / \mathrm{ml})$ for $16 \mathrm{~h}$ at $37^{\circ} \mathrm{C}(n=4-5)$.

Incubation with FCS and TGF- $\beta$ caused a significant increase of ET-1 PCR product both in glomeruli and IMCD (Fig. 4, $a$ and $b$ ). The internal standard, GAPDH, showed almost the same intensity with and without FCS/TGF- $\beta$. Thus, FCS and TGF- $\beta$ selectively increases the ET- 1 mRNA level in glomeruli and IMCD.

\section{Discussion}

Our present data clearly show that ET-1 production occurs in the glomeruli and the IMCD along the nephron. ET-1 mRNA expression determined by RT-PCR, and ET-1 production assayed by RIA, completely agreed with this conclusion. Taking into account that the glomeruli and the collecting ducts are the target sites of ET-1 $(2,3,11,13,14,20-25)$, our data suggest that ET-1 is an autocrine (and paracrine) factor in glomeruli and IMCD.

ET was originally found in culture medium of vascular smooth muscle cells (1). Epithelial cells as well as endothelial cells have become known to produce ET-1 (2, 3, 26-28). Cell lines, such as MDCK or LLC-PK ${ }_{1}$ cells, have been used to show that epithelial cells can produce ET-1. Recently, cultured tubular cells from PCT, MAL, CCD, and IMCD were also reported to produce ET-1 $(29,30)$. However, it has not been known whether intact renal tubules can produce ET-1. We used an ET-1-specific antibody for radioimmunoassay (34). There was almost no cross-reactivity with ET-2 or ET-3. Since the amount of ET-1 produced by intact nephron segments was quite small, we had to dissect nephron segments $>150 \mathrm{~mm}$ in length. This small amount of ET-1 production may indicate that ET-1 is important as a local hormone rather than a circulating one.

Recently, Moriyama et al. (35) and Terada et al. (36) introduced a new method to detect specific mRNA in single microdissected renal tubules using RT-PCR. Using this technique, relative quantitation of $\mathrm{mRNA}$ coding for peptide hormone receptor was performed from only 2-mm-long renal tubules (36). We did not purify RNA from renal tubules, so genomic DNA might have contaminated the samples. We designed two primers to localize in separate exons to distinguish the PCR amplification product by genomic DNA from cDNA, which is synthesized by mRNA (38). We could not detect any band when PCR amplification was performed without RT. This result indicated the presence of intron sequences between the primers, which prevented PCR amplification. It seems likely that the amplification product from genomic DNA is too big for Taq polymerase to amplify efficiently. Therefore, PCR products from glomeruli and IMCD must not originate from genomic DNA but from mRNA.

We used 40 cycles of PCR to detect ET-1 mRNA along the nephron. These reaction conditions should result in maximal amplification, allowing us to determine whether ET-1 mRNA was present in various portions of nephron segments. In contrast, we used 30 cycles of PCR to determine the effect of FCS and TGF- $\beta$ on mRNA in glomeruli and IMCD, since a previous study showed that the linearity between PCR cycles and PCR products ( $m R N A$ ) was seen at $\leq 30$ cycles of PCR (36).

Histological studies showed that binding sites of ET-1 are mainly in glomeruli, IMCD, and the vascular system, and slightly in proximal tubules $(5,15,16,18)$. Functional studies showed that the target sites of ET-1 in the kidney are glomeruli, whole collecting ducts, and the vascular system $(11,13,14$, 20-25). We could not detect ET-1 mRNA in proximal tubules and CCD and OMCD. However, immunostaining study (18) showed slight staining of ET-1-like immunoreactivity in PCT. The ET-1-like immunostaining in PCT was mainly in the most proximal portion of the proximal tubule brush border. This immunostaining may represent reabsorption of urinary ET-1 by the brush border, however, functional effects of ET-1
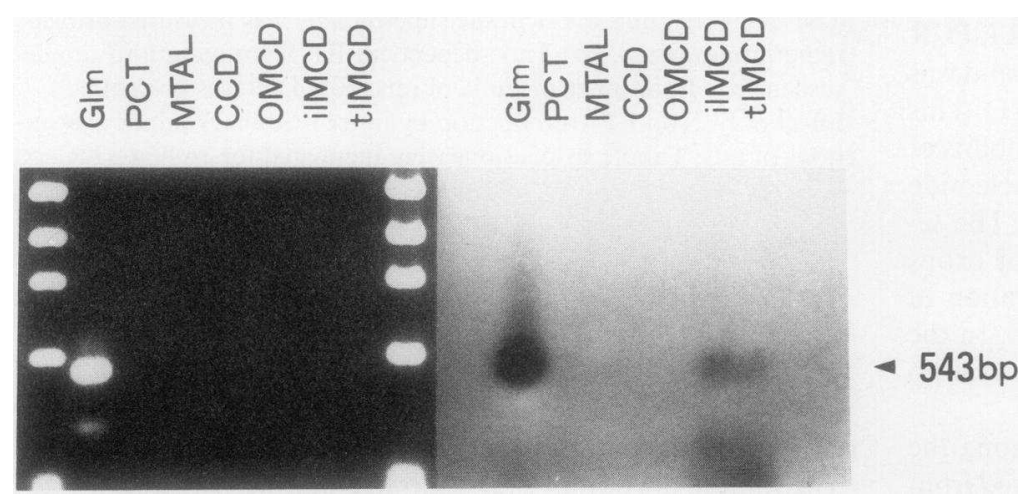

Figure 3. ET-1 mRNA distribution along rat nephron segments. Five glomeruli and 2-mm-long nephron segments ( $P C T, M A L, C C D, O M C D, I M C D$ ) were used for RT-PCR. The left panel shows the result from agarose gel electrophoresis, and the right panel shows the Southern blot analysis. 


\section{FCS TGF- $\beta$}

a A

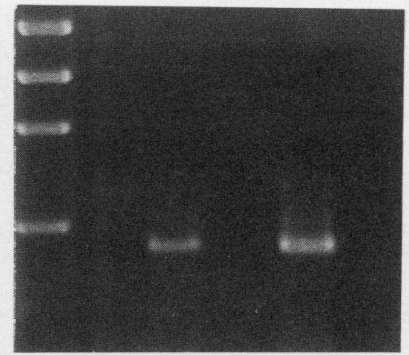

$-543 \mathrm{bp}$
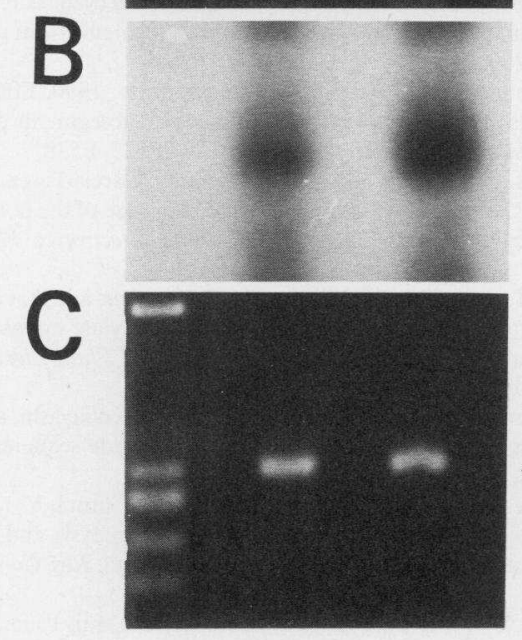

-309 bp

\section{FCS \\ TGF- $\beta$}

b

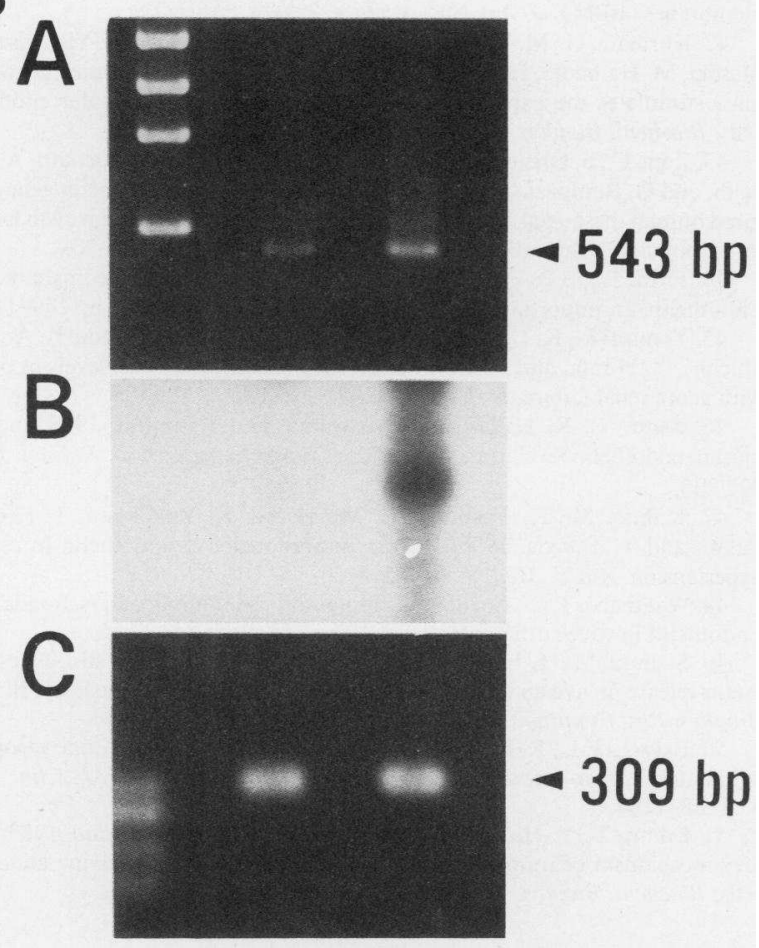

in proximal tubules have been reported $(19,40,41)$. ET-1 has been shown to inhibit AVP-stimulated cAMP accumulation not only in IMCD but in CCD and OMCD (20). ET-1 may act as a paracrine factor in proximal tubules and $C C D$ and OMCD. On the other hand, ET-1 mRNA and ET-1 production were observed in glomeruli and IMCD, where ET-1 has several functional effects. This strongly suggests that ET-1 is an autocrine factor in glomeruli and IMCD.

The strongest stimulator of ET-1 production in vitro was FCS. ET-1 production without FCS in tubule suspensions from inner medulla was quite small. Although a small band of ET-1 mRNA was observed after the incubation of IMCD without FCS, the addition of FCS to the incubation medium greatly increased ET-1 mRNA expression. Similar effects were observed in glomeruli. It is not known what components in the serum stimulated ET- 1 production. TGF- $\beta$ is also known to stimulate ET-1 production in several tissues $(28,42,43)$. The plasma ET-1 concentration increases in several diseases, such as acute and chronic renal failure, essential hypertension, myocardial infarction, and endotoxin shock (44-49). The sites of ET-1 production in these diseases are not known. The vascular system and glomeruli could be the site of ET-1 production in these diseases. Another possibility is that these diseases may stimulate the production of cytokines, such as interleukin, TGF- $\beta$, or TNF- $\alpha$, which increase ET- 1 synthesis. In particular, TGF- $\beta$ has been shown to increase in inflammation. AVP and angiotensin-II are also known to stimulate ET-1 production in glomeruli and cultured bovine endothelial cells ( 50 , 51 ). It is not known whether IMCD-derived ET-1 increases in these diseases. ET-1 produced by IMCD could be important for natriuresis and diuresis as an autocrine factor. ET-1 has been shown to inhibit AVP-stimulated osmotic water permeability in tIMCD, and active chloride and water reabsorption in CCD $(24,25)$. ET-1 is thought to cause natriuresis by inhibiting AVP-dependent cAMP accumulation through stimulation of protein kinase- $C$ in collecting ducts (20). The presence of local regulation of body fluid homeostasis by ET-1 in IMCD would be important for water and electrolyte balance. It would be quite interesting to know the sites and mechanisms of ET-1 production in pathophysiological conditions.

In summary, we demonstrated that ET-1 mRNA, determined by RT-PCR, and ET-1 synthesis, assayed by RIA, were detected only in glomeruli and IMCD among nephron segments. These data clearly demonstrated that the sites of ET-1 production along the nephron are glomeruli and IMCD. ET-1 may act as an autocrine factor in glomeruli and IMCD.

\section{Acknowledgments}

We thank Dr. Robert A. Star (University of Texas Southwestern Medical Center) for reading the manuscript and giving us useful suggestions.

This work was supported in part by a Grant-in-Aid for Scientific research from the Ministry of Education (02670273, 02770326).

Figure 4. Effect of FCS and TGF- $\beta$ on ET-1 mRNA expression in ( $a)$ microdissected glomeruli and $(b)$ IMCD. Five glomeruli or $10-\mathrm{mm}$ IMCDs were incubated with or without $10 \%$ FCS plus TGF- $\beta$ ( 16 $\mathrm{ng} / \mathrm{ml}$ ) for $6 \mathrm{~h}$ before RT-PCR. $A$ shows the result from agarose gel electrophoresis, $B$ shows the Southern blot analysis. GAPDH is shown in $C$ of both panels as an internal standard. 


\section{References}

1. Yanagisawa, M., H. Kurihara, S. Kimura, Y. Tomobe, M. Kobayashi, Y. Mitsui, Y. Yazaki, K. Goto, and T. Masaki. 1988. A novel potent vasoconstrictor peptide produced by vascular endothelial cells. Nature (Lond.). 332:411-415.

2. Brenner, B. M., J. L. Troy, and B. J. Ballermann. 1989. Endothelium-dependent vascular responses. J. Clin. Invest. 84:1373-1378.

3. Kon, V., and K. F. Badr. 1991. Biological actions and pathophysiologic significance of endothelin in the kidney. Kidney Int. 40:1-12.

4. Inoue, A., M. Yanagisawa, S. Kimura, Y. Kasuya, T. Miyauchi, K. Goto, and T. Masaki. 1989. The human endothelin family: three structurally and pharmacologically distinct isopeptides predicted by three separate genes. Proc. Natl. Acad. Sci. USA. 86:2863-2867.

5. Koseki, C., M. Imai, Y. Hirata, M. Yanagisawa, T. Maski. 1989. Autoradiographic distribution in rat tissues of binding sites for endothelin: a neuropeptide? Am. J. Physiol. 256 (Regulatory Integrative Comp. Physiol. 25):R858-R866.

6. Arai, H., S. Hori, I. Aramori, H. Ohkubo, and S. Nakanishi. 1990. Cloning and expression of CDNA encoding an endothelin receptor. Nature (Lond.). 348:730-732.

7. Sakurai, T., M. Yanagisawa, Y. Takuwa, H. Miyazaki, S. Kimura, K. Goto, and T. Masaki. 1990. Cloning of a cDNA encoding a non-isopeptide-selective subtype of the endothelin receptor. Nature (Lond.). 348:732-735.

8. Terada, Y., K. Tomita, H. Nonoguchi, and F. Marumo. 1992. Different localization of two types of endothelin receptor mRNA in microdissected rat nephron segments using reverse transcription and polymerase chain reaction assay. J. Clin. Invest. 90:107-112.

9. Goetz, K. L., B. C. Wang, J. B. Madwed, J. L. Zhu, and R. J. Leadley, Jr. 1988. Cardiovascular, renal and endocrine responses to intravenous endothelin in conscious dogs. Am. J. Physiol. 255 (Regulatory Integrative Comp. Physiol. 24):R1064-R 1068.

10. Miller, W. L., M. M. Redfield, and J. C. Burnett. 1988. Integrated cardiac, renal and endocrine actions of endothelin. J. Clin. Invest. 83:317-320.

11. Badr, K. F. J. J. Murray, M. D. Breyer, K. Takahashi, T. Inagami, and R. C. Harris. 1989. Mesangial cell, glomerular and renal vascular responses to endothelin in the rat kidney. J. Clin. Invest. 83:336-342.

12. King, A. J., B. M. Brenner, and S. Anderson. 1989. Endothelin: a potent renal and systemic vasoconstrictor peptide. Am. J. Physiol. 256 (Renal Fluid Electrolyte Physiol. 25):F1051-F1058.

13. Kon, V., T. Yoshioka, A. Fogo, and I. Ichikawa. 1989. Glomerular actions of endothelin in vivo. J. Clin. Invest. 83:1762-1767.

14. Simonson, M. S., and M. J. Dunn. 1990. Endothelin-1 stimulates contraction of rat glomerular mesangial cells and potentiates beta-adrenergic-mediated cyclic adenosine monophosphate accumulation. J. Clin. Invest. 85:790-797.

15. Kohzuki, M., C. I. Johnston, S. Y. Chai, D. J. Casley, and F. A. O. Mendelsohn. 1989. Localization of endothelin receptors in rat kidney. Eur. $J$. Pharmacol. 160:193-194.

16. Jones, C. R., C. R. Hiley, J. T. Pelton, and R. C. Miller. 1989. Autoradiographic localisation of endothelin binding sites in kidney. Eur. J. Pharmacol. 163:379-382.

17. Koseki, C., Y. Hayashi, S. Torikai, M. Furuya, N. Ohnuma, and M. Imai. 1986. Localization of binding sites for $\alpha$-rat atrial natriuretic polypeptide in rat kidney. Am. J. Physiol. 250 (Renal Fluid Electrolyte Physiol. 19):F210-F216.

18. Wilkes, B. M., M. Susin, P. F. Mento, C. M. Macica, E. P. Girardi, E. Boss, and E. P. Nord. 1991. Localization of endothelin-like immunoreactivity in rat kidneys. Am. J. Physiol. 260 (Renal Fluid Electrolyte Physiol. 29):F913-F920.

19. Garvin, J., and K. Sanders. 1991. Endothelin inhibits fluid and bicarbonate transport in part by reducing $\mathrm{Na}^{+} / \mathrm{K}^{+}$ATPase activity in the rat proximal straight tubule. J. Am. Soc. Nephrol. 2:976-982.

20. Tomita, K., H. Nonoguchi, and F. Marumo. 1990. Effects of endothelin on peptide-dependent cyclic adenosine monophosphate accumulation along the nephron segments of the rats. J. Clin. Invest. 85:2014-2018.

21. Zeidel, M. L., H. R. Brady, B. C. Kone, S. R. Gillans, and B. M. Brenner. 1989. Endothelin, a peptide inhibitor of $\mathrm{Na}^{+} / \mathrm{K}^{+}$-ATPase in intact renal tubular epithelial cells. Am. J. Physiol. 257 (Cell Physiol. 26):C1101-C1107.

22. Simonson, M. S., S. Wann, P. Mene, G. R. Dubyak, M. Kester, Y. Nakazato, J. R. Sedor, and M. J. Dunn. 1989. Endothelin stimulates phospholipase C $\mathrm{Na}^{+} / \mathrm{H}^{+}$exchange, c-fos expression, and mitogenesis in rat mesangial cells. $J$. Clin. Invest. 83:708-712.

23. Naruse, M., S. Uchida, E. Ogata, and K. Kurokawa. 1991. Endothelin 1 increases cell calcium in mouse collecting tubule cells. Am. J. Physiol. 261 (Renal Fluid Electrolyte Physiol. 30):F720-F725.

24. Oishi, R., H. Nonoguchi, K. Tomita, and F. Marumo. Endothelin-1 inhibits vasopressin-stimulated osmotic water permeability in the inner medullary collecting duct of rats. Am. J. Physiol. 261 (Renal Fluid Electrolyte Physiol. 30):F951-F956.

25. Tomita, K., H. Nonoguchi, and F. Marumo. 1990. Endothelin inhibits fluid absorption in rat cortical collecting ducts. J. Am. Soc. Nephrol. 1:427a. (Abstr.)

26. Mardsen, P. A., D. M. Dorfman, T. Collins, B. M. Brenner, S. H. Orkin and B. J. Ballermann. 1990. Regulated expression of endothelin 1 in glomerular capillary endothelial cells. Am. J. Physiol. 261 (Renal Fluid Electrolyte Physiol. 30):F117-F125.

27. Sakamoto, H., S. Sasaki, Y. Hirata, T. Imai, K. Ando, T. Ida, T. Sakurai, M. Yanagisawa, T. Masaki, and F. Marumo. 1990. Production of endothelin 1 by rat cultured mesangial cells. Biochem. Biophys. Res. Commun. 169:452-468.

28. Horie, M., S. Uchida, M. Yanagisawa, Y. Matsushita, K. Kurokawa, and E. Ogata. 1991. Mechanisms of endothelin-1 mRNA and peptides induction by TGF- $\beta$ and TPA in MDCK cells. J. Cardiovasc. Pharmacol. 17(Suppl. 7):S222S225.

29. Kohan, D. E. 1991. Endothelin synthesis by rabbit renal tubule cells. Am. J. Physiol. 261 (Renal Fluid Electrolyte Physiol. 30):F221-F226.

30. Kohan, D. E., and F. T. Fiedorek, Jr. 1991. Endothelin synthesis by rat inner medullary collecting duct cells. J. Am. Soc. Nephrol. 2:150-155.

31. MacCumber, M. W., C. A. Ross, B. M. Glaser, and S. H. Snyder. 1989. Endothelin: visualization of mRNAs by in situ hybridization provides evidence for local action. Proc. Natl. Acad. Sci. USA. 86:7285-7289.

32. Ando, K., Y. Hirata, M. Shichiri, T. Emori, and F. Marumo. 1989. Presence of immunoreactive endothelin in human plasma. FEBS (Fed. Eur. Biochem. Soc.) Lett. 245:164-166.

33. Nonoguchi, H., M. A. Knepper, and V. C. Manganiello. 1987. Effects of atrial natriuretic factor on cyclic guanosine monophosphate and cyclic adenosine monophosphate accumulation in microdissected nephron segments from rats. $J$. Clin. Invest. 79:500-507.

34. Ujiie, K., H. Nonoguchi, K. Tomita, and F. Marumo. 1990. Effects of ANF on cGMP synthesis in inner medullary collecting duct subsegments of rats. Am. J. Physiol. 259 (Renal Fluid Electrolyte Physiol. 28):F535-F538.

35. Moriyama, T., H. R. Murphy, B. M. Martin, and A. Garcia-Perez. 1990. Detection of specific mRNAs in single nephron segments by use of the polymerase chain reaction. Am. J. Physiol. 258 (Renal Fluid Electrolyte Physiol. 27):F1470-F1474.

36. Terada, Y., T. Moriyama, B. M. Martin, M. A. Knepper, and A. GarciaPerez. 1991. RT-PCR micro-localization of mRNA for guanylate cyclase-coupled ANF receptor in rat kidney. Am. J. Physiol. 261 (Renal Fluid Electrolyte Physiol. 30):F1080-F1087.

37. Inoue, A., M. Yanagisawa, Y. Takuwa, Y. Mitsui, M. Kobayashi, and T. Masaki. 1989. Human preproendothelin-1 gene. The nucleotide sequence and regulation of expression. J. Biol. Chem. 264:14954-14959.

38. Sakurai, T., M. Yanagisawa, A. Inoue, U. S. Ryan, S. Kimura, Y. Mitsui, K. Goto, and T. Masaki. 1991. cDNA cloning, sequence analysis and tissue distribution of rat preproendothelin-1 mRNA. Biochem. Biophys. Res. Commun. 175:44-47.

39. Fort, P., L. Marty, M. Piechaczyk, S. E. Sabrouty, C. Dani, P. Jeanteur, and J. M. Blanchard. 1985. Various rat adult tissues express only one major mRNA species from the glyceraldehyde-3-phosphate-dehydrogenase multigene family. Nucleic Acids Res. 13:1431-1442.

40. Harris, P. J., and D. Thomas. 1990. Effects of endothelin-1 (ET) on proximal tubule fluid reabsorption. J. Am. Soc. Nephrol. 1:416a. (Abstr.)

41. Guntupalli, J., R. Phelps, and T. D. DuBose. 1991. Effect(s) of endothelin-1 (ET) on Na- $\mathrm{P}_{\mathrm{i}}$ cotransport and $\mathrm{Na}^{+}-\mathrm{H}^{+}$exchange in rat renal brush border membranes (BBM). J. Am. Soc. Nephrol. 2:402a. (Abstr.)

42. Kurihara, H., M. Yoshizumi, T. Sugiyama, T. Takaku, M. Yanagisawa, T. Masaki, M. Hamaoki, H. Kato, and Y. Yazaki. 1989. Transforming growth factor- $\beta$ stimulates the expression of endothelin mRNA by vascular endothelial cells. Biochem. Biophys. Res. Commun. 159:1435-1440.

43. Zoja, C., S. Orisio, N. Perico, A. Benigni, M. Morigi, L. Benatti, A. Rambaldi, and G. Remuzzi. 1991. Constitutive expression of endothelin gene in cultured human mesangial cells and its modulation by transforming growth factor- $\beta$, thrombin, and a thromboxane $\mathrm{A}_{2}$ analogue. Lab. Invest. 64:16-20.

44. Firth, J. D., P. J. Ratcliffe, A. E. Raine, and J. G. G. Ledingham. 1988 Endothelin: an important factor in acute renal failure? Lancet. ii:1179-1182.

45. Tomita, K., K. Ujiie, T. Nakanishi, S. Tomura, O. Matsuda, K. Ando, M. Shichiri, Y. Hirata, and F. Marumo. 1989. Plasma endothelin levels in patients with acute renal failure. $N$. Engl. J. Med. 321:1127.

46. Saito, Y., K. Nakao, M. Mukoyama, and H. Imura. 1990. Increased plasma endothelin level in patients with essential hypertension. $N$. Engl. J. Med. 322:205.

47. Kohno, M., K. Yasunari, K. Murakawa, K. Yokokawa, T. Horio, T Fukui, and T. Takeda. 1990. Plasma immunoreactive endothelin in essential hypertension. Am. J. Med. 88:614-618.

48. Watanabe, T., N. Suzuki, N. Shimamoto, M. Fujino, and A. Imada. 1990 Endothelin in myocardial infarction. Nature (Lond.). 344:114.

49. Sugiura, M., T. Inagami, and V. Kon. 1989. Endotoxin stimulates endothelin-release in vivo and in vitro as determined by radioimmunoassay. Biochem. Biophys. Res. Commun. 161:1220-1227.

50. Bakris, G. L., R. Fairbanks, and A. M. Traish. 1991. Arginine vasopressin stimulates human mesangial cell production of endothelin. J. Clin. Invest. 87:1158-1164

51. Emori, T., Y. Hirata, K. Ohta, M. Scichiri, and F. Marumo. 1989. Secretory mechanism of immunoreactive endothelin in cultured bovine endothelial cells. Biochem. Biophys. Res. Commun. 160:93-100. 